\title{
PARENTING STYLE AND THE LEVEL \\ OF ISLAMISM AMONG SENIOR HIGH SCHOOL STUDENTS IN YOGYAKARTA
}

\author{
Muhammad Wildan | UIN Sunan Kalijaga Yogyakarta - Indonesia \\ Alimatul Qibtiyah | UIN Sunan Kalijaga Yogyakarta - Indonesia \\ Corresponding author: muhammad.wildan@uin-suka.ac.id
}

\begin{abstract}
Along with the rise of global Islamism, religious extremism has recently become a serious threat in Indonesia, especially among the youth. In addition to the influences of online media and school environments, religious extremism among youth is also caused by family factor. Based on questionnaire-based data from 802 respondents of 20 senior high schools, this research explores the influence of parenting styles on the level of Islamism among senior high school students in Yogyakarta. The research finds that parents in Yogyakarta have implemented an authoritative or democratic parenting style more than other styles. Also, school girls tend to receive democratic parenting styles more than their boy counterparts. More than that, male and female students posit a medium level on Islamism except on the issue of terrorism. On the attitude of terror, most respondents $(93.9 \%)$ are on the low level, only $1.2 \%$ of respondents are on the medium level, and no one is on the high level of terror. The paper further says that teenagers who live with the so-called authoritarian parents tend to have a high risk of intolerant attitude. In contrast, authoritative or democratic and permissive parenting styles contribute less to an intolerant attitude.
\end{abstract}

Keywords: Islamism, parenting style, violent attitude and extremism

\section{Introduction}

Violent extremism and terrorism have been growing as a significant threat to the world. ${ }^{1}$ The global jihad of Osama bin Laden and the call of caliphate (Islamic State) by Abu Bakar Al-Baghdady

1 Boaz Ganor, Global Alert: the Rationality of Modern Islamist Terrorism and the Challenge to the Liberal Democratic World (New York: Columbia University Press, 2015), pp. 1-11. 
have socked the world and influenced the rise of Islamism and radicalism locally in many countries. In Indonesian context, many devastated bombings in the name Jamaah Islamiyah (Al-Qaeda branch in Southeast Asia) and Jamaah Anshorut Daulah (IS affiliation) have killed many innocent civilians. ${ }^{2}$ Currently, although the number of violent extremism decreased significantly in term of numbers and casualties, radicalism and the spread of extremism ideology are still quite a substantial threat for Indonesia. The National Agency for Counter Terrorism (Badan Nasional Penanggulangan Terorisme, BNPT) and Soufan Center have indicated that hundreds Indonesians went home from Syria either as Foreign Terrorist Fighters (FTF), returnees, or deportees. $^{3}$

Currently, the threat of Islamism in Indonesia lies more on the spread of extremism ideology among youth. Many researches have been done to reveal to what extent does the ideology of extremism and radicalism have increased and endangered the nation-state of Indonesia. Center for the Study of Islam and Society (PPIM) of the State Islamic University (UIN) Jakarta underlines that youth is the main target of the spread of radical ideologies. In its research in 34 provinces, PPIM found that the intolerance and radical ideologies among school teachers and students are quite high. ${ }^{4}$ In the same way, Setara Institute also found that some big and well-known universities in Indonesia have been exposed to radicalism ideologies. Finally, Maarif Institute has also found that the gate of extremism and radical ideologies among school students are Islamic study club (Kerohanian Islam.$^{5}$

2 ICG, "Jemaah Islamiyah in South East Asia: Damaged but still Dangerous," ICG Asia Report, No. 63 (Jakarta: International Crisis Group, 2013); IPAC, "The Surabaya Bombings and The Future of ISIS in Indonesia," IPAC Report, No. 51 (Jakarta: Institute for Policy Analysis of Conflict, 2018).

3 Richard Barret, Beyond the Caliphate: Foreign Fighters and the Threat of Returnees (New York: The Soufan Center, 2017).

4 PPIM-UNDP, Pelita yang Meredup: Keberagamaan Guru Sekolab/Madrasah di Indonesia (Jakarta: PPIM-UNDP, 2018); Farah \& Yuni, "Redam Radikalisme Butuh Pendidikan Keagamaan Inklusif," from: https://www.uinjkt.ac.id/id/toleransi-keragaman-butuhpendidikan-ke agama-inklusif (accessed on December 8, 2019).

5 Muhd. Abdullah Darraz \& Zuly Qodir, "OSIS Mendayung di Antara Dua Karang: Kebijakan Sekolah, Radikalisme, dan Inklusivisme Kebangsaan," Convey Report, Vol. 1, No. 4 (Jakarta: PPIM -MAARIF Institute-UNDP Indonesia, 2018). 
Many approaches have been conducted to see the root or factors of radical or extremist ideology. ${ }^{6}$ Conservative approach maintains that ideology and economic are the root factors of radical and extremist ideology, some others tend to see that education also play a significant role in shaping extremism. The most current approach conducted by Noor Huda Ismail tends to see radicalism from the perspective of masculinity. ${ }^{7}$ Nowadays, there is a shifting trend in terrorism - discussion and planning of which can be said to have moved from the "backyard" to the "dining room". Violence is being openly discussed at the dinner table and engagement in terrorist acts defies gender stereotypes. Women are increasingly involved in acts of violent extremism. Mia Bloom asserts that between 1985 and 2010, female bombers around the world committed over 257 suicide attacks (representing about a quarter of the total), ${ }^{8}$ while Ness estimates that women and girls now make up to between 30 to 40 percent of the combatants in numerous ethnic separatist/guerrilla struggles. ${ }^{9}$ In 2017, the Turkish government reported that among 75 Indonesian returnees from Syria who joined ISIS, 70 per cent of whom were women and children. ${ }^{10}$

Based on the fact that radical and extremism ideology could be easily widely spread through family and kinship, ${ }^{11}$ this paper attempts to see the associations between parenting style which according to Diana Baumrind includes permissive, authoritarian, and authoritative and emotional and behavioral problems of the children especially on the ideology of Islamism. To examine the level of Islamism of the students, this paper uses four categories of Islamism, i.e., conservatism,

6 See among others Akh. Muzakki, "The Roots, Strategies, and Popular Perception of Islamic Radicalism in Indonesia," Journal of Indonesian Islam, Vol. 08, No. 01 (June 2014), pp. 1-22.

7 Cameron Sumpter, "Returning Indonesian Extremists: Unclear Intentions and Unprepared Responses," ICCT Policy Brief July 2018. DOI: 10.19165/2018.2.05

8 Mia Bloom, "Bombshells: Women and Terror," in Gender Issues, 28, 1-2 (2011), pp. 1 21.

9 Cindy D. Ness, "The Rise in Female Violence," in Daedalus, 136, 1, on Nonviolence \& Violence (Winter, 2007), pp. 84-93.

10 Noor Huda Ismail, “CVE and Communication," (Unpublished paper presented to Workshop on CVE and Communication by YPP (Jakarta, 2017).

11 Noor Huda Ismail, "Al-Qaeda's Southeast Asia, Jamaah Islamiyah and Regional Terrorism: Kinship and Family," The Asia-Pacific Journal, 5, 1 (2007), pp. 1-10. 
militant, extremism, terrorism. This tendency of violent extremism ideology employs the combination of Noorhaidi Hasan's index of Islamism ${ }^{12}$ and Bassam Tibi's concept of Islamism. ${ }^{13}$ By studying this relationship hopefully could contribute to the government's efforts and other stakeholders having the same concern on combating violent extremism ideology among the youth. Yogyakarta was chosen based on the previous researches concluding that senior high school students in Yogyakarta more vulnerable to be influenced with radical views or extremism ideology. ${ }^{14}$

Many studies have been conducted to see the relationship between parenting style and children's emotional development and behavior. However, little is known about the relationship between parenting style and religion, especially within Muslim families. There is also a lack of research that focuses on the effects of all three parenting styles (i.e. authoritarian, authoritative, permissive) on child development in Muslim families. It is necessary, therefore, to study further on the role of parents in shaping children's behaviorur especially in the perspective of parenting style.

Given the complexities of the radicalism problem in Indonesia, it is necessary to include the family approach as preventing violent extremism (PVE). The role of the family is very important in preventing radicalism through the partnership between husband and wife. Education of children is not only the duty of the wife but is the responsibility of the father. Besides, the harmonious relationship between husband and wife through family partnerships is the main capital in preventing radicalism. ${ }^{15}$ This strategy is absolutely needed to strengthen the government's initiatives to tackle the threat and the spread of extremism ideology.

12 Noorhaidi Hasan (ed.), Laporan Nasional: Narasi dan Politik Identitas: Pola Penyebaran dan Penerimaan Radikalisme dan Terorisme di Indonesia. Unpublished joint research report of UIN Sunan Kalijaga with the Indonesia's National Counter Terrorism Agency (BNPT) and Terrorism Prevention Coordination Forum (FKPT), 2013.

13 Bassam Tibi, Islamism and Islam (New Haven: Yale University Press, 2012), p. vii.

14 Hairus Salim, Najib Kailani, \& Nikmal Azekiyah, Politik Ruang Publik Sekolah Negosiasi dan Resistensi di Sekolah Menengah Umum Negeri di Yogyakarta (Yogyakarta: CRCS, 2011); Ismail Hasani \& Bonar Tigor Naipospos, Dari Radikalisme Menuju Terorisme Studi Relasi dan Transformasi Organisasi Islam Radikal di Jawa Tengab \& D.I. Yogyakarta (Jakarta: Pustaka Masyarakat Setara, 2013).

15 Zidni Ervi, “Kemitraan Keluarga dalam Menangkal Radikalisme," Jurnal Online Studi Al-Qur'an, 14, 1 (2018), pp. 32-42. 
In this sense, a comprehensive anti-terrorism project that focusing on the family roles and school targeted to parents and teenagers is quite crucial to be an alternative strategy. The emotional boundary between parents and kids, the choice of parenting style, the type of religious thought and the media are very important factors to look at. The family has significant roles to fulfil save the environment, enjoyment, social welfare and spiritual needs. Every family has a different parenting style to educate their kids. Culture, ethnicity and the way they learn from the ancestor are the important factors to determine the parenting styles. This research is designed to answer all those issues which focuses on how the parenting style influence the level of Islamism among senior high school students.

This research employs a quantitative method using questionnaire and documentation. The questionnaire is used for collecting data of parenting styles and the tendency of violent extremism ideology. The data are collected from 20 senior high schools at Yogyakarta Special Region through purposive sampling method. As each school took about 20 respondents, total respondents are 802 students. On the tendency of violent extremism ideology, this research employed Noorhaidi Hasan's index of Islamism which was combined with Bassam Tibi's concept of Islamism namely conservatism, militant, extremism, and terrorism. To acquire qualified data of the above Islamism index, each parameter was represented by 4-6 questions on Islam and politics. To examine the influence of the dependent variable (the attitude toward violent and extremism ideology) into independent variables (gender, area, and parenting styles), this study employed regression bivariate SPSS analysis. To see the different between the variables this research implemented the Independent Sample Tests. The research steps include: 1) literature studies to create measurement or assessment that include the indicators and operational explanation of dependent and independent variable (the attitude toward violence and extremism ideology-gender, area, and parenting styles). 2) Try out, 3) Collecting quantitative data, and 4) Data analysis.

\section{Parenting Styles}

Many radicalism cases in Indonesia proved that family especially parents play a significant role in shaping children's behavior. The family suicide bombers in Surabaya and Malang proven the role of parents in shaping the mind and ideology of the children. Quite similar 
cases are the Foreign Terrorist Fighters (FTF) in Syria who bring along with them their wives and children. Some other cases such as two senior high school students involved in radical group in Klaten (2011), church bomb in Medan (2016), police post in Surakarta (2018) have involved teenagers. Therefore, further deep researches are needed to see the role of the parent in the above phenomena, based on some news on media found that they may grow from the permissive parent.

Noor Huda Ismail's research which he documented on "Jihad Selfie" (2016) and "Seeking the Imam" (2020) movies reveal that the role of parent is very significant on children's behavior. ${ }^{16}$ While the youth were interested and recruited by extremism through social media, the children still rely on much to their parents especially their mother. Although in urban modern family the parenting involves mother and father, culturally believed that mother has more significant roles in parenting. To reduce the influence of violent extremism ideology, it is very important to pay attention to the role of parents especially the mother.

The parents' type of religious understanding is also a significant factor in the parenting style. The simplest categories of religious understanding are a textualist, moderate, and progressive. ${ }^{17}$ The textualist people tend to understand religious texts literally, moderate people tend to understand religious text in moderate ways, whereas progressive people tend to understand texts more contextually. As far as the authors concerned, extremists and radicals tend to employ textual approach in understanding religious texts. ${ }^{18} \mathrm{~A}$ research on religious parenting style found that "the more religious parents are perceived as 'better' parents by their off-spring, they are regarded as better at communication, support, monitoring and peer acceptance, as well as maintaining closeness and managing conflict." Furthermore, Jan Horwarth and Janet Lees after reviewing seventy-seven papers on

16 Hanna Azarya Samosir, "Film Jihad Selfie, Mengungkap Alasan "Remeh" WNI Gabung ISIS," CNN Indonesia. https://www.cnnindonesia.com/internasional/ 20160823083014-106-153170/ film-jihad-selfie-mengungkap-alasan-remeh-wni-gabung-isis.

17 Alimatul Qibtiyah, “'Mapping of Muslims' Understandings on Gender Issues in Islam at Six Universities in Yogyakarta," Al-Jami'ah, 25, 2 (2018), pp. 211-230.

18 Roel Meijer (ed.), Global salafism: Islam's New Religious Movement (UK: C. Hurst \& Co. Publishers, 2009); Rolan Gunawan \& Lies Marcoes-Natsir, Inspirasi Jihad Kaum Jihadis: Telaah atas Kitab-kitab Jihad (Jakarta: Rumah Kitab, 2017). 
religion and parenting conclude that the religious belief impact on parenting. ${ }^{19}$

Relating to parental control, Diana Baumrind explains three types of parenting styles: permissive, authoritarian, and authoritative. The permissive style is defined as "parent attempts to behave in a nonpunitive, acceptant, and affirmative manner toward the child's impulses, desires, and actions". It follows a tolerant approach for the sake of children's socialization. The parents mostly ignore misconduct displayed by children. The parents do not maintain control over their children's conduct, but they exhibit a tolerant and supportive attitude. Permissive parents allow their children to experience a high level of freedom and do not impose rules and regulation to restrain their practices unless physical harm is expected. The authoritarian style is defined as "parent's attempt to shape, control, and evaluate the behavior and attitudes of children in accordance with a set standard, theologically motivated and formulated by a higher authority". Authoritarian parent exhibits an unfriendly attitude with their children and demands them to follow rules and decision without any argument. Authoritarian parents restrain children's self-expression and freedom desires and use power-assertive techniques (physical force, love withdrawal, commands, threats) to achieve what they want from their children. Finally, the authoritative style which is defined as "parents attempts to direct the children's activities in a rational, issues-oriented manner". ${ }^{20}$ This style is also known as democratic style which prioritize the interests of children or child centeredness. The type of democratic parenting is not much use of control over the children. Parents put themselves as a friend and guide in the family. This type is among the best types of parenting. Democratic parenting style shows that they live happily and quite confident in mastering new tasks and able to control themselves for refusing to engage in unfavourable action.

\footnotetext{
19 Jan Horwath \& Janet Lees, "Assessing the Influence of Religious Beliefs and Practices on Parenting Capacity: The Challenges for Social Work Practitioners," British Journal of Social Work, 40, 1 (2010), pp. 82-99.

20 Diana Baumrind, "Effects of Authoritative Parental Control on Child Behavior," Child Development, 37, 4 (1996), pp. 887-907.
} 


\section{Islamism and Religious Ideology}

Islamism is a visionary movement to shape world records based on religion and allow violence which has six spectrums namely 1) Purification of Islam, 2) Formalization of Islamic Sharia, 3) AntiDemocracy, 4) Anti-other religions, 5) Anti-Western culture and 6) Agree to use violence for achieving the goals. Meanwhile, Oliver Roy defines that Islamism is the new name of Modern Islamic politics that wants to create an Islamic society (ummab) and Islamic countries through political actions and enforces the formalization of Islamic sharia. ${ }^{21}$ In Indonesia, Islamism had existed long before independence. However, when the New Order operated illegally and since the reformation era, Islamism has gained space to exist and develop until it is legally included in political parties.22

There are four types of Muslim from the violence-prone extremist jihadist core to more peaceful Muslims: Jihadist Muslims, Islamist Muslims, Conservative Muslims and Pluralist Muslims: ${ }^{23}$ Jihadist Muslims want to impose their interpretation of Islam on all others by the threat or use of force in order to achieve their submission and conversion. They also most militant ones and are mainly interested in fighting the 'near enemy'. Whilst Islamist Muslims may not practice violence but often adhere to the same, or a similar, fundamentalist and exclusivist ideology as the jihadist terrorists. In principle, they are opposed to pluralism, but for practical and pragmatic reasons, they opt for coexistence with other political parties. Conservative Muslims tend not to view Islam as a political ideology and are not revolutionary. Conservatism is a belief that all fundamental doctrines of Islam especially Islamic purification and Syariah should be implemented, militant is a belief having intolerant thought and tend to disregard other believers, extremism is a belief that political concept should be implemented revolutionary even though through violent actions, and

21 Oliver Roy, Globalized Islam: The Search for a New Ummah (Columbia: Columbia University Press, 2004).

22 Moch Nur Ichwan, "Islamisme, Pos-Islamisme, dan Reposisi Islam Mainstream: Sebuah Pendahuluan," Moch Nur Ichwan \& Muhammad Wildan (eds.), Islamisme dan Pos-Islamisme: Dalam Dinamika Politik Indonesia Kontemporer (Yogyakarta: SUKA-Press and CISForm, UIN Sunan Kalijaga Yogyakarta, 2019); RE Elson, "Islam, Islamism, the Nation, and the Early Indonesian Nationalist Movement," Journal of Indonesian Islam, 1, 2 (2007), pp. 231-266.

23 Alex P. Schmid, "Moderate Muslims and Islamist Terrorism: Between Denial and Resistance," The International Centre for Counter-Terrorism-The Hague, 8, 9 (2017), pp. 1-28. 
terrorism is violent actions in the name of religious values which are conducted systematically. ${ }^{24}$ Some call them as traditional Muslim. While Pluralist Muslims adhere to a broader interpretation of what it means to be Islamic and are inclusivists rather than exclusivists regarding various expressions of their faith and its relationship to other faiths. They include 'modern Muslims', 'cultural Muslims', 'sociological Muslims', 'liberal Muslims', 'reformist Muslims', 'progressive Muslims', 'Western Muslims', 'Muslim democrats' and the 'Muslim left'. Based on those classifications, the first to the third group tends to close to Islamism. The word Islamism has various definitions. But in general, the term Islamism appears as a substitute for the term fundamentalism and the term political Islam which tends to be stigmatic. ${ }^{25}$

\section{Social Backgrounds of Respondents}

The respondents were selected from 20 schools in 4 districts and 1 municipality in Yogyakarta Special Region. The 20 schools comprise of 12 public schools, 4 public religious schools, and 4 private religious schools. These schools are deliberately chosen as they are among the best and favorite schools in its respected district. All the public schools are under the ministry of education, the public religious schools are under the ministry of religious education, and the private religious schools are under Mubammadiyah and Nadlatul Ulama (NU). It is also necessary to mention that among 20 schools, there are also 3 boarding schools. The diverse schools were intentionally chosen to acquire good result for the research.

Table 1. Social Backgrounds of Respondents $(\mathrm{N}=802)$

\begin{tabular}{llccc}
\hline \multirow{2}{*}{$\begin{array}{c}\text { SOCIAL } \\
\text { BACKGROUNDS }\end{array}$} & CATEGORY & \multicolumn{2}{c}{ NUMBER (802) } & PERCEN- \\
\cline { 3 - 4 } & & $\begin{array}{c}\text { MALE } \\
\text { TAGE }\end{array}$ & $\begin{array}{c}\text { FEMALE } \\
\text { TAGE }\end{array}$ & $\begin{array}{c}\mathbf{( 2 9 6 )} \\
\mathbf{( 5 0 6 )}\end{array}$ \\
\hline Religion & Islam & 290 & 488 & $97 \%$ \\
& Other Islam & 6 & 18 & $3 \%$
\end{tabular}

\footnotetext{
${ }^{24}$ Noorhaidi Hasan (ed.), Laporan Nasional: Narasi dan Politik Identitas: Pola Penyebaran dan Penerimaan Radikalisme dan Terorisme Di Indonesia. (Yogyakarta: Unpublished joint research report of UIN Sunan Kalijaga with BNPT and FKPT, 2013).

25 Muhammad Wildan (eds), Menanam Benih di Ladang Tandus: Potret Sistem Produksi Guru Agama Islam di Indonesia. (Yogyakarta: CISForm \& PPIM, 2019); Husniyatus Salamah Zainiyati, "Curriculum, Islamic Understanding and Radical Islamic Movements in Indonesia," Journal of Indonesian Islam, 10, 2 (2016), pp. 285-308.
} 


\begin{tabular}{|c|c|c|c|c|}
\hline \multirow{2}{*}{$\begin{array}{c}\text { SOCIAL } \\
\text { BACKGROUNDS }\end{array}$} & \multirow[t]{2}{*}{ CATEGORY } & \multicolumn{2}{|c|}{ NUMBER (802) } & \multirow{2}{*}{$\begin{array}{c}\text { PERCEN- } \\
\text { TAGE } \\
(\%)\end{array}$} \\
\hline & & $\begin{array}{c}\text { MALE } \\
\text { (296) }\end{array}$ & $\begin{array}{c}\text { FEMALE } \\
(506)\end{array}$ & \\
\hline Educational & Public School & 96 & 389 & $60 \%$ \\
\hline Backgrounds & Religious School & 128 & 189 & $40 \%$ \\
\hline \multirow[t]{3}{*}{ Grade } & Grade X & 48 & 260 & $48 \%$ \\
\hline & Grade XI & 104 & 172 & $40 \%$ \\
\hline & Grade XII & 28 & 74 & $12 \%$ \\
\hline \multirow[t]{4}{*}{ Living with } & Parents & 215 & 337 & $68 \%$ \\
\hline & Relatives & 6 & 15 & $3 \%$ \\
\hline & Boarding & 64 & 137 & $25 \%$ \\
\hline & Others & 11 & 17 & $4 \%$ \\
\hline \multirow{4}{*}{$\begin{array}{l}\text { The fulfilment of } \\
\text { basic need }\end{array}$} & Mostly Fulfilment & 90 & 226 & $40 \%$ \\
\hline & Few Fulfilment & 186 & 264 & $57 \%$ \\
\hline & Not Fulfilment & 9 & 9 & $2 \%$ \\
\hline & Not Answer & 5 & 6 & $1 \%$ \\
\hline \multirow{4}{*}{$\begin{array}{l}\text { Using internet to } \\
\text { learn religious } \\
\text { values }\end{array}$} & 0-1 Hours & 208 & 334 & $63 \%$ \\
\hline & 1-3 Hours & 68 & 140 & $27 \%$ \\
\hline & 3-5 Hours & 11 & 17 & $5 \%$ \\
\hline & $>5$ Hours & 9 & 15 & $5 \%$ \\
\hline \multirow{4}{*}{$\begin{array}{l}\text { Resources of } \\
\text { religious teachings }\end{array}$} & Boarding & 80 & 170 & $31.5 \%$ \\
\hline & $\begin{array}{l}\text { TPA (afternoon Islamic } \\
\text { school) }\end{array}$ & 47 & 42 & $11 \%$ \\
\hline & Public Islamic Preaching & 139 & 255 & $49 \%$ \\
\hline & Organization & 30 & 39 & $8.5 \%$ \\
\hline Type of Parents' & Literal & 74 & 94 & $21.2 \%$ \\
\hline \multirow[t]{2}{*}{ Religious Thought } & Moderate & 194 & 368 & $70.6 \%$ \\
\hline & Contextual/progressive & 22 & 44 & $8.2 \%$ \\
\hline \multirow[t]{3}{*}{ Parenting Style } & Authoritative & 112 & 378 & $61.21 \%$ \\
\hline & Authoritarian & 103 & 125 & $29.95 \%$ \\
\hline & Permissive & 30 & 54 & $11.85 \%$ \\
\hline
\end{tabular}

Based on the above data, we can see those female respondents are 63\% and male are 37\%; Muslim respondents are 97\% and others are $3 \%$; respondents from public school and from religious school are $60 \%$ and $40 \%$ respectively; and respondents from $10^{\text {th }}$ grade are $48 \%$, from $11^{\text {th }}$ grade are $40 \%$, and from $12^{\text {th }}$ grade is $12 \%$.

On religious aspects, it is important to see the sources of Islamic teachings of the youth. In term of the sources of religious teachings, about $49 \%$ of the respondents acknowledged that they attended public Islamic preaching (pengajian umum) and only $11 \%$ who attended afternoon Islamic school (TPA-Taman Pendidikan Al Qur'an). This data 
explains that most respondents learned religious teaching from conventional resources such as Pengajian/Taklim (public Islamic preaching). In Yogyakarta context, almost every mosque organizes Islamic gathering weekly, fortnightly and monthly. Therefore, it makes sense that majority students gained religious teachings from those religious meetings. In addition, it is also interesting that as millennial, most participants $(63 \%)$ only have internet access about 1 hour per day to search religious teachings.

On the other social aspects, we could see that most respondents $(68 \%)$ live with their parents and only $25 \%$ who live at boarding school (pesantren). This number indicates that the role of parents is very important for their kids. On their basic need, it is only 3\% of them perceive that their basic need is not fulfilled. It means that most respondents perceive that their basic needs such as access to education, health, clothing and food have been fulfilled.

Finally, on the parents' religious thoughts (textual, moderate and progressive), we could conclude from the chart that the majority of the respondents' parents are moderate $(70.6 \%)$ which is followed by textual $(21.2 \%)$ and then progressive $(8.2 \%)$. In addition, there are 10 items used to measure the type of parents' religious thought which include the way to understand religious text, the friendship with those have different religious affiliation, halal food, the gender role, inheritance, men and women leadership, polygamy, hijab, bank interest and performing prayer.

\section{Youth's Level of Islamism and Its Association with Parenting Styles}

\section{Level of Islamism among Youth in Yogyakarta}

It would be interesting to see the level of Islamism among senior high school students. As we could conclude from some previous researches that senior high school students in Yogyakarta are quite susceptible to be influenced by conservative and extremism ideology and that internal student organization, i.e., ROHIS is the access of this ideology. ${ }^{26}$ Based on Islamism Index, we would measure the level of Islamism which is classified into four categories namely: conservative, militant, extremist, and terrorist.

26 Muhd. Abdullah Darraz \& Zuly Qodir, "OSIS Mendayung di Antara Dua Karang: Kebijakan Sekolah, Radikalisme, dan Inklusivisme Kebangsaan," Convey Report, Vol. 1, No. 4, 2018. (Jakarta: PPIM, MAARIF Institute and UNDP Indonesia, 2018). 
Table 2. The level of Islamism among youth in Yogyakarta

\begin{tabular}{lcccccccc}
\hline & \multicolumn{2}{c}{ Conservative } & \multicolumn{2}{c}{ Militant } & \multicolumn{2}{c}{ Extremism } & \multicolumn{2}{c}{ Terrorism } \\
\hline Level & Number & $\mathbf{\%}$ & Number & $\mathbf{0}$ & Number & $\mathbf{\%}$ & Number & \% \\
\hline No & 6 & .7 & 15 & 1.9 & 5 & .6 & 39 & 4.9 \\
Answer & & & & & & & & \\
Low & 56 & 7.0 & 351 & 43.8 & 101 & 12.6 & 753 & 93.9 \\
Medium & 661 & 82.4 & 372 & 46.4 & 619 & 77.2 & 10 & 1.2 \\
High & 79 & 9.9 & 64 & 8.0 & 77 & 9.6 & - & - \\
\hline
\end{tabular}

In general, based on Table 2, senior high school students in Yogyakarta posit a medium level on Islamism except on the level of terrorism. The respondents' attitude on each questions of Islamism index result quite significant number (relatively high at medium level), i.e., conservative is about $82.4 \%$, then followed by militant on $46.4 \%$, and extremism on $77.2 \%$. While on the terrorism level shows very low attitude $(1.2 \%)$ at medium level and no response at the high level. To conclude, although the above data shows that Islamism index of the students in Yogyakarta is relatively high at medium level, in general it could be categorized as average. This can be seen that at the high level of all Islamism category was responded very low.

\section{Parenting Style in Yogyakarta}

As one of the main objectives of this research is to examine the association of students' level of Islamism and parenting styles, our finding on this issue are as follow:

Table 3. Parenting Styles Based on Areas

\begin{tabular}{|c|c|c|c|c|}
\hline \multirow[t]{2}{*}{ NO } & \multirow[t]{2}{*}{ AREAS } & \multicolumn{3}{|c|}{ PARENTING STYLES } \\
\hline & & AUTHORITATIVE & AUTHORITARIAN & PERMISSIVE \\
\hline 1. & $\begin{array}{l}\text { City of } \\
\text { Yogyakarta }\end{array}$ & $63 \%$ & $25 \%$ & $12 \%$ \\
\hline 2. & $\begin{array}{l}\text { District of } \\
\text { Sleman }\end{array}$ & $63 \%$ & $26 \%$ & $11 \%$ \\
\hline 3. & $\begin{array}{l}\text { District of } \\
\text { Kulon } \\
\text { Progo }\end{array}$ & $59 \%$ & $29 \%$ & $12 \%$ \\
\hline 4. & $\begin{array}{l}\text { District of } \\
\text { Bantul }\end{array}$ & $61 \%$ & $27 \%$ & $12 \%$ \\
\hline 5. & $\begin{array}{l}\text { District of } \\
\text { Gunung } \\
\text { Kidul }\end{array}$ & $61 \%$ & $27 \%$ & $12 \%$ \\
\hline \multicolumn{2}{|c|}{ TOTAL } & $61.21 \%$ & $29.95 \%$ & $11.85 \%$ \\
\hline
\end{tabular}


Based on Table 3, the majority of parenting style in Yogyakarta in general is authoritative (democratic) which comprise of $61.21 \%$, followed by authoritarian parenting style which posit approximately $29.95 \%$, and then permissive which posit about $11.85 \%$. Although each of the district has quite same number in each of the parenting style, Yogyakarta municipality and Sleman district relatively higher in term of Authoritative Parenting Style compared to other towns/districts. In addition, Kulon Progo district has the least on this parenting style. It means that the relationship between parents and their children is more egalitarian in Yogyakarta municipality and Sleman district than other places. Almost one third of parents in Kulon Progo district implement the authoritarian parenting style. In other words the relationship between parent and their children tend to imbalance.

Table 4. Parenting Styles Based on Gender

\begin{tabular}{llllcl}
\hline $\begin{array}{c}\text { Parenting } \\
\text { Style }\end{array}$ & Gender & N & Mean & $\begin{array}{c}\text { Std. } \\
\text { Deviation }\end{array}$ & $\begin{array}{c}\text { Std. } \\
\text { Error } \\
\text { Mean }\end{array}$ \\
\hline Authoritative & Male & 290 & 50.0862 & 10.02921 & .58894 \\
& Female & 506 & 52.4543 & 10.23129 & .45484 \\
Authoritarian & Male & 290 & 23.7546 & 6.45746 & .37919 \\
& Female & 506 & 21.9967 & 6.26450 & .27849 \\
Permissive & Male & 290 & 9.7462 & 2.96776 & .17427 \\
& Female & 506 & 10.1174 & 3.84152 & .17078 \\
\hline
\end{tabular}

Table 5. Youth's Level of Islamism and its Association with Parenting Styles

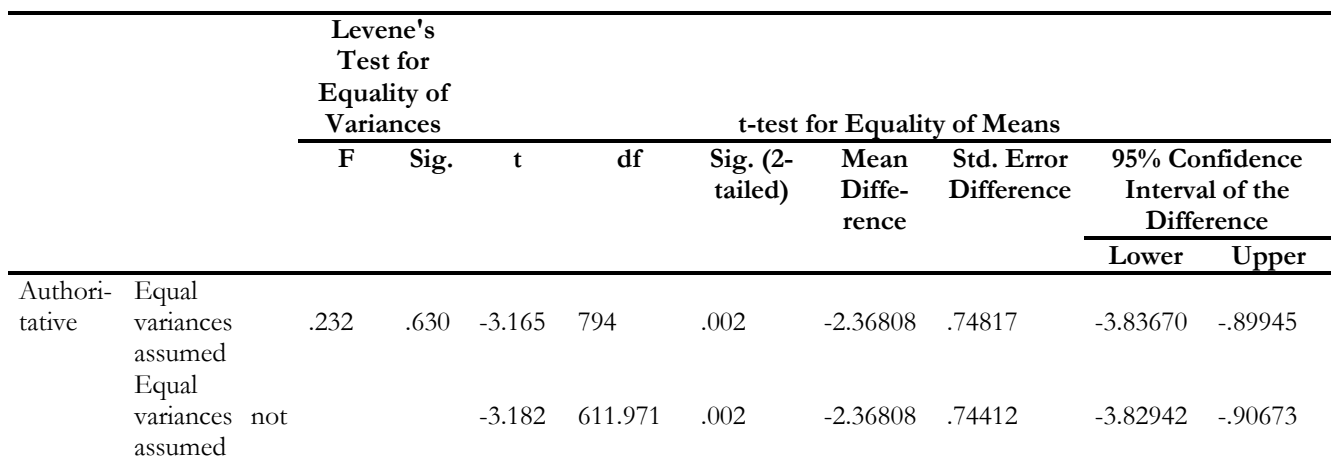




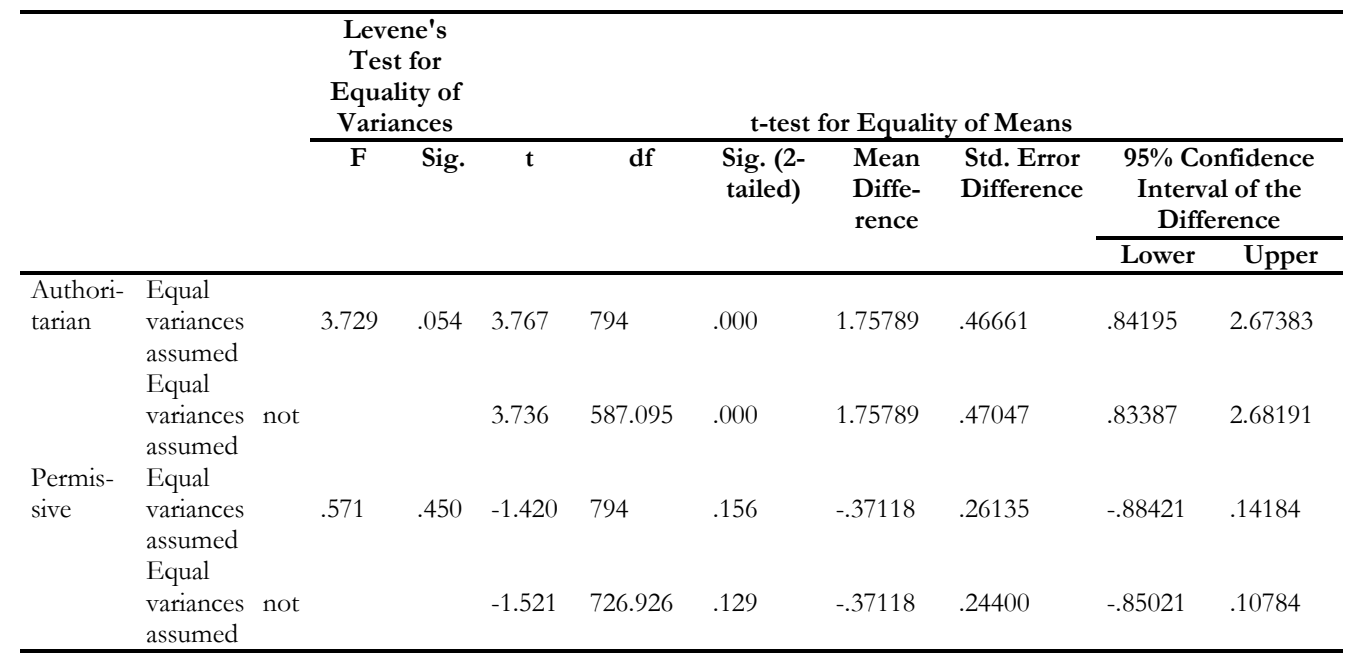

It is interesting, however, that there are differences between male and female senior high school students in receiving parenting style at home. From Table 4 we could conclude that female students tend to receive authoritative (democratic) parenting style than their male counterparts. Similar case is also happened to permissive parenting style. In contrast, male students tend to receive authoritarian parenting style from their parents than their female counterparts. The difference on parenting style based on gender can be seen from Table 4. There is a very significant difference of authoritarian parenting style based on gender Sig.(2-tailed), 0.000 which is under 0.01. Although girls tend to receive more permissive parenting style, the different between gender is not quite significant, Sig. (2-tailed), 0.129 which is above 0.05 .

\section{The Association of Parenting Style and the Level of Youth's Islamism}

It is interesting to see the correlation between the youth index Islamism and parenting style. By implementing SPSS Correlation Bivariate, this research finds (Table 5) that authoritative parenting style has a significant correlation (only) with the extremism attitude Sig. (2tailed) 0.018 (under 0.05) and do not have any correlation with other Islamism. In the same way, there is a very significant correlation of authoritarian parenting style with militant attitude, Sig. (2-tailed) 0.000 and on extremism attitude, Sig. (2-tailed) 0.013. While, permissive 
parenting style have a significant correlation with militant attitude Sig. (2-tailed) 0.003 .

Table 6. The Association of Parenting Style and the level of Youth's Islamism

\begin{tabular}{llcccc}
\hline & & Conservative & Militant & Extremism & Terrorism \\
\hline Authori & Pearson Correlation & -.014 & .018 & $.084^{*}$ & .025 \\
tative & Sig. (2-tailed) & .688 & .620 & .018 & .475 \\
& $\mathrm{~N}$ & 802 & 802 & 802 & 802 \\
Authori & Pearson Correlation & .062 & $.152^{* *}$ & $.088^{*}$ & .045 \\
tarian & Sig. (2-tailed) & .079 & .000 & .013 & .199 \\
& $\mathrm{~N}$ & 802 & 802 & 802 & 802 \\
Permis & Pearson Correlation & .006 & $.104^{* *}$ & .059 & -.003 \\
sive & Sig. (2-tailed) & .860 & .003 & .095 & .939 \\
& $\mathrm{~N}$ & 802 & 802 & 802 & 802 \\
& Sig. (2-tailed) & .000 & .000 & .000 & \\
& $\mathrm{~N}$ & 802 & 802 & 802 & 802 \\
\hline
\end{tabular}

*. Correlation is significant at the 0.05 level (2-tailed).

**. Correlation is significant at the 0.01 level (2-tailed).

Table 6 also explains that authoritative parenting styles do not have significant correlation toward the three level of students' Islamism namely, conservative, militant, and terrorism. It is also happened to permissive parenting styles that there is no significant correlation between this parenting style toward three (conservative, extremism, and terrorism) levels of Islamism among students in Yogyakarta. However, there is very significant correlation between the authoritarian parenting style and the level of youth Islamism, in particular on militant and extremism levels. The correlation of authoritative or democratic parenting style to the level youth Islamism can be seen on Table 6 (conservative attitude: 0.688, Militant: 0.620, and terrorist: 0.475). Those score are more than 0.05 , sig (2 tailed) except on Extremism: 0.018. It means that there is no correlation if the score above 0.05 . In other world authoritative or democratic parenting style does not contribute to high risk of youth Islamism. Similar idea occurs to the permissive parenting style which is there is no also correlation between flexible or not rigid parenting style and the level of Islamism (conservative attitude: 0.860, Extremism: 0.95, and terrorist: 0.939) except on Militant: 0.003. In contrast to other two parenting styles, authoritarian or rigid parenting style have a very significant correlation to the level of Islamism, in particular on militant and extremist 
tendencies. It means that parents who implement authoritarian style influence the youth's Islamism. In other world teenager who live with authoritarian parents tend to have high risk on intolerant attitude. This conclusion is based on the correlation score sig (2 Tailed) on militant 0.000 and extremism 0.013 .

Based on the above research data, we found that 1) in line with other previous studies, Islamism index of senior high school students in Yogyakarta is relatively high (at medium level). This is proven by the quantitative data which revealed the ideology of conservatism and extremism among the students is quite high (at medium level), militant is relatively lower, and in term of terrorism is very low. In addition, the parenting style of most senior high school students' parents in Yogyakarta is authoritative (democratic).

On the first phenomenon that Islamism index of Yogyakarta students' is relatively high (at medium level), there are at least two factors which may influence. First, students' religious activities at their respective schools as having been indicated by previous researches play a profound role in shaping students' belief and attitude. Student organization such as ROHIS plays a vital role in bringing religious activities in the schools. Second, the overwhelm of Islamism narratives and propaganda in social media including conservatism and extremism Islamic values also have also influenced and built students' ideology.

On the second phenomenon that parenting style of students in Yogyakarta is authoritative (democratic), we could state that it has significant correlation with students' attitude of Islamism. On the democratic parenting style, we could state that Yogyakarta as a student city gives a more democratic atmosphere for Yogyakarta people. Although the schools as the subjects of this research are located in many different districts in Yogyakarta, these schools are among favorite educational institutions in their respected areas. Sequentially, these schools are more favorable among middle-class and educated people who have enough knowledge of parenting. One significant example of democratic parenting style in the region is the parenting program in the society namely Indabnya Membangun Kebersamaan Keluarga (IMKK). The program aims at building cooperation between all parties in creating a conducive climate for children's growth and development. In addition, this program includes good parenting, reproductive health education, personality education, pre-marital education, household management education, conflict management, effective 
communication of community and entrepreneurial teamwork. Among urban villages in Yogyakarta, Wirobrajan is a representative of Yogyakarta's best model of parenting style. ${ }^{27}$

In addition, Harianti finds that democratic parents who always encourage their children to be involved in family decision making will bring about status of achievement identity. Conversely, authoritarian parents, who control their children's behavior without giving them opportunities to express their opinions, will encourage the status of foreclosure identity. Meanwhile, permissive parents who do not provide sufficient direction for their children and let them make their own decisions will encourage the status of diffusion identity. Further, Harianti explains that parenting style will have something to do with the youth expression of anger which could lead to the levels of violence. ${ }^{28}$ Likewise, Tiofita Arista concludes that there is a relationship between the democratic parenting with the expressions of anger among adolescents in Yogyakarta city. Therefore, democratic parenting pattern has an important role in the level of juvenile delinquency and violence.

Further, this research indicates that the role of parental religious thought does not have a significant influence on the attitude of Islamism of their children. The parental religious thinking is divided into three categories, namely conservative, moderate and progressive. Conversely, Ciciek Farha finds that radicalism which grows in public education institutions is mostly brought by its religious teachers. ${ }^{29}$ In the same way, Wahid Institute in its research in public schools reveals that $82 \%$ of the respondents actively attended Kerohanian Islam/ROHIS (religious activities) in schools, and more than $20 \%$ of the respondents admitted to hear opinions leading to radicalism. Furthermore, $78 \%$ of the respondents supports the idea of the caliphate, $33 \%$ aggree that jibad is war, taking up arms against infidels, and $60 \%$ are ready to fight if there is a call to defend oppressed Muslims like in Palestine. To

27 Kurniatul Hidayah, "Wirobrajan Jadi Wakil Kota Yogya di Lomba Pola Asuh Anak Tingkat Nasional," https://jogja.tribunnews.com/2018/09/04/ wirobrajan-jadi-wakilkota-yogya-di-lomba-pola-asuh-anak-tingkat-nasional

28 Mini Harianti, Hubungan Pola Asub Orang Tua dengan Konsep Diri Remaja di SMAN 11 Banda Aceb Tabun 2012 (Aceh: Universitas Syiah Kuala, 2012).

29 Ciciek Farha (ed.), Laporan Penelitian: Kaum Muda dan "Regenerasi" Gerakan Fundamentalis di Indonesia: Studi tentang Unit Kerohanian Islam di SMU Negeri (Jakarta: Rahima, 2008). 
conclude, violent and radical attitudes of senior high students are mostly influenced by religious values they acquire during in schools either form their formal religious teachers or from their religious mentors of ROHIS activities, and also from the parenting style of their parents. ${ }^{30}$

Parenting style is divided into three types, namely authoritative, authoritarian and permissive. While authoritative style is described as a democratic parenting style, which is quite responsive and demanding children, the authoritarian style tends to demand and expect maturity from their children, and permissive style tends to give full freedom to their children and does not impose strict rules and regulations, except to be involved in crime. Eventually, this study concludes that authoritative parenting style of the parents does not have any significant influence on the violent and radical attitudes of the students. This type of parenting style even has a good role in preventing violent and radical activities. This is also in line with Tina T. Dyches, Timothy B. Smith, Byran B. Korth, Susanne Olsen Roper, Barbara Mandleco that authoritative parenting style is apparently positive parenting style. ${ }^{31}$

Meanwhile, an authoritarian parenting style tends to lead students to be offensive and even radical. This study shows sig (2-tailed) with errors of $10 \%, 5 \%$ and $1 \%$ that a violent and radical attitude in the form of a conservative of 0.059 , militant of 0.000 , extreme of 0.12 and terrorist 0.001 . Based on these data authoritarian parenting tends to be militant, radical, and terrorist with a $1 \%$ error. This means that almost all parenting patterns have an influence on militant and radical attitudes among adolescents in Yogyakarta. The research of CRCS (2011) at "Rajawali" High School in Yogyakarta found that "Islamist" movement at senior high school was mostly influenced by its alumni through extracurricular activities. In other words, when the parenting style tends to be authoritarian, the attitude of the students will be likely to be influenced or even dominated by others which later on could lead to aggressive, militant, and even radical.

Conversely, permissive parenting style which basically allows their children to learn about life themselves could potentially lead them into

30 Alamsyah (ed.), Laporan: Riset Potensi radikalisme di Kalangan Aktivis Rohani Islam sekolah-sekolah Negeri (Jakarta: Wahid Institute, 2016).

31 Diana Baumrind, "Effects of Authoritative Parental Control on Child Behavior," Child Development, 37, 4 (1996), pp. 887-907. 
militant sig (2-tailed) 0.10. This means that permissive parenting style has even a potential role to the children to be tolerant, supportive, high level of freedom, and maintaining a friendly reciprocal relationship if the parenting style in the family has good control.

Conclusively, each type of parenting style has a quite significant role in creating the attitudes of children to be violent or radical. Parenting is closely related to the quality of the relationship between parents and the children. ${ }^{32}$ The most important element of parenting style is to socialize and indigenize the children into the dominant culture. ${ }^{33}$ Although there are also many children could be successful without the presence of their parent, it is true that parental involvement in education is an important resource for the success of the children. ${ }^{34}$ Therefore, one of the keys to the success of the children depends much on the parenting style of their parents.

\section{Conclusion}

In line with the previous researches on the levels of Islamism on the students, the research found that the levels of Islamism among senior high school students in Yogyakarta is relatively high (at medium level) especially in conservatism, militant, and extremism with the numbers consecutively 82.4\%, 46.4\%, and $77.2 \%$. From the measurement at the high level we could see that this phenomenon which is relatively low, i.e., conservative (9.8\%), militant $(8.0 \%)$, extremism $(9.6 \%)$, and terrorism $(0.0 \%)$.

When we relate the above phenomenon with parenting style, the research found that among three different levels of parenting styles (authoritative, authoritarian, and permissive) the parents of the students in Yogyakarta mostly tend to be authoritative with the number $61.21 \%$. From this number, we could see that there is a lack of a significant influence between authoritative (and permissive) parenting styles on the level of students' Islamism. However, we could also see that the authoritarian parenting style has a significant influence on the

\footnotetext{
32 Jon Ivar Elstad \& Kari Stefansen, "Social Variations in Perceived Parenting Styles among Norwegian Adolescents," Child Indicators Research, 7, 1 (2014), pp. 649-670.

33 Nancy Darling \& Laurence Steinberg, "Parenting Style as Context: An Integrative Model," Psychological Bulletin, 113, 3 (1993), pp. 487-496.

34 Mido Chang, Boyoung Park, and Sunha Kim, "Parenting Classes, Parenting Behavior, and Child Cognitive Development in Early Head Start: A Longitudinal Model," The School Community Journal, 19, 1 (2009), p. 155.
} 
level of Islamism among the students at Yogyakarta. The research also found that there is no much influence of parents' religious thought on students' levels of Islamism.

On the above phenomena, we could underline that 1) nowadays parents have limited influence on students thought and attitude, 2) students are more tempted with some conservative to extreme values of Islam due to the increase of global Islamism and the advance of information technology. However, this research suggests that the levels of independence of the students are relatively high nowadays; the students to many extents are much more informative and knowledgeable especially on many contemporary issues rather than their parents. However, the presence of parents is considered still being significant to maintain the stability of students' emotion. []

\section{References}

Alamsyah (ed.). Laporan: Riset Potensi Radikalisme di Kalangan Aktivis Rohani Islam Sekolah-Sekolah Negeri. Jakarta: Wahid Institute, 2016.

Baumrind, Diana. "Effects of Authoritative Parental Control on Child Behavior." Child Development, 37, 4 (1996), pp. 887-907.

Bloom, Mia. "Bombshells: Women and Terror." Gender Issues, 28, 1-2, (2011), pp. 1-21.

Chang, Mido, Boyoung Park, and Sunha Kim. "Parenting Classes, Parenting Behavior, and Child Cognitive Development in Early Head Start: A Longitudinal Model." The School Community Journal, 19, 1 (2009), pp. 155-174.

Darling, Nancy., \& Laurence Steinberg. "Parenting Style as Context: An Integrative Model." Psychological Bulletin, 113, 3 (1993), pp. 487-496.

Darraz, Muhd. Abdullah and Zuly Qodir. "OSIS Mendayung di Antara Dua Karang: Kebijakan Sekolah, Radikalisme, dan Inklusivisme Kebangsaan." Convey Report 1, 4 (Jakarta: PPIM -MAARIF Institute-UNDP Indonesia, 2018).

Elson, RE. "Islam, Islamism, the Nation, and the Early Indonesian Nationalist Movement." Journal of Indonesian Islam, 1, 2 (2007), pp. 231-266. 
Elstad, Jon Ivar \& Kari Stefansen. "Social Variations in Perceived Parenting Styles among Norwegian Adolescents." Child Indicators Research, 7, 1 (2014), pp. 649-670

Ervi, Zidni. "Kemitraan Keluarga dalam Menangkal Radikalisme." Jurnal Online Studi Al-Qur'an, 14 (2018), pp. 32-42.

Farah \& Yuni. "Redam Radikalisme Butuh Pendidikan Keagamaan Inklusif". https://www.uinjkt.ac.id/id/toleransi-keragamanbutuh-pendidikan-keagamaan-inklusif/ (accessed 18 December 2019).

Gunawan, Rolan \& Lies Marcoes-Natsir. Inspirasi Jibad Kaum Jihadis: Telaah atas Kitab-kitab Jihad. Jakarta: Rumah Kitab, 2017.

Harianti, Mini. Hubungan Pola Asub Orang Tua dengan Konsep Diri Remaja di SMAN 11 Banda Aceh Tahun 2012. Aceh: Universitas Syiah Kuala, 2012.

Hasani, Ismail \& Bonar Tigor Naipospos. Dari Radikalisme Menuju Terorisme Studi Relasi dan Transformasi Organisasi Islam Radikal Di Jawa Tengah \& D.I. Yogyakarta. Jakarta: Pustaka Masyarakat Setara, 2012.

Hasan, Noorhaidi (ed.). Laporan Nasional: Narasi dan Politik Identitas: Pola Penyebaran dan Penerimaan Radikalisme dan Terorisme Di Indonesia. Yogyakarta: Unpublished joint research report of UIN Sunan Kalijaga with Badan Nasional Penanggulangan Terorisme (BNPT) and Forum Koordinasi Pencegahan Terorisme (FKPT), 2013.

Horwath, Jan \& Janet Lees. "Assessing the Influence of Religious Beliefs and Practices on Parenting Capacity: The Challenges for Social Work Practitioners." British Journal of Social Work, 40, 1 (2010), pp. 82-99.

ICG. "Jemaah Islamiyah in South East Asia: Damaged but still dangerous." ICG Asia Report, No. 63. Jakarta: International Crisis Group, 2003.

IPAC. "The Surabaya Bombings and The Future of ISIS in Indonesia." IPAC Report, No. 51. Jakarta: Institute for Peace Analysis of Conflicts, 2018.

Hidayah, "Wirobrajan Jadi Wakil Kota Yogya di Lomba Pola Asuh Anak Tingkat Nasional." https://jogja.tribunnews.com/2018/- 
09/04/wirobrajan-jadi-wakil-kota-yogya-di-lomba-pola-asuhanak-tingkat-nasional (accessed on 20 June 2019).

Ismail, Noor Huda. "Qaeda's Southeast Asia, Jamaah Islamiyah and Regional Terrorism: Kinship and Family Links." The Asia-Pacific Journal, 5, 1 (2007), pp. 1-10.

. "CVE And Communication." Unpublished paper presented to Workshop on CVE and Communication. Jakarta: Yayasan Prasasti Perdamaian, 2017.

Ichwan, Moch Nur. "Islamisme, Pos-Islamisme, dan Reposisi Islam Mainstream: Sebuah Pendahuluan." Moch Nur Ichwan \& Muhammad Wildan (eds). Islamisme dan Pos-Islamisme: Dalam Dinamika Politik Indonesia Kontemporer. Yogyakarta: SUKA-Press and CISForm UIN Sunan Kalijaga Yogyakarta, 2019.

Meijer, Roel (ed.). Global Salafism: Islam's New Religious Movement. UK: C. Hurst \& Co. Publishers, 2009.

Muzakki, Akh. "The Roots, Strategies, and Popular Perception of Islamic Radicalism in Indonesia." Journal of Indonesian Islam, Vol. 08, No. 01 (June 2014), pp. 1-22.

Ness, Cindy D., "The Rise in Female Violence." Daedalus 136, 1, on Nonviolence \& Violence (Winter 2007), pp. 84-93.

PPIM-UNDP, Pelita yang Meredup: Keberagamaan Guru Sekolah/Madrasah di Indonesia. Jakarta: PPIM-UNDP, 2018.

Qibtiyah, Alimatul. "'Mapping of Muslims' Understandings on Gender Issues in Islam at Six Universities in Yogyakarta." Al-Jami'ah, 25, 2 (2018), pp. 211-230.

Roy, Oliver. Globalized Islam: The Search for a New Ummah. Columbia University Press, 2004.

"Redam Radikalisme Butuh Pendidikan Keagamaan Inklusif". https://www.uinjkt.ac.id/id/toleransi-keragaman-butuh-pendidikan-keagamaan-inklusif/

Samosir, Hanna Azarya. "Film Jihad Selfie, Mengungkap Alasan "Remeh" WNI Gabung ISIS." CNN Indonesia. https://www.cnnindonesia.com/internasional/20160823083014-106-153170/ film-jihad-selfie-mengungkap-alasan-remeh-wni-gabung-isis. 
Schmid, Alex, P. "Moderate Muslims and Islamist Terrorism: Between Denial and Resistance." The International Centre for CounterTerrorism 8, 9 (2017), pp. 1-28.

Salim, Hairus, Najib Kailani \& Nikmal Azekiyah. Politik Ruang Publik Sekolah Negosiasi dan Resistensi di Sekolah Menengah Umum Negeri di Yogyakarta. Yogyakarta: CRCS, 2011.

Sumpter, Cameron. "Returning Indonesian Extremists: Unclear Intentions and Unprepared Responses." ICCT Policy Brief (July 2018).

Tibi, Bassam. Islamism and Islam. New Haven: Yale University Press, 2012.

Wildan, Muhammad (eds). Menanam Benih di Ladang Tandus: Potret Sistem Produksi Guru Agama Islam di Indonesia. Yogyakarta: CISForm \& PPIM, 2019.

Zainiyati, Husniyatus Salamah. "Curriculum, Islamic Understanding and Radical Islamic Movements in Indonesia." Journal of Indonesian Islam, 10, 2 (2016), pp. 285-308. 